\title{
Human capital accounting: A literature review
}

\author{
Remi Chukwudi Okeke*
}

Department of Public Administration and Local Government, University of Nigeria, Nsukka, Nigeria

\begin{tabular}{l}
\hline C H R O N I C L E \\
\hline Article history: \\
Received June 5, 2015 \\
Received in revised format \\
August 162015 \\
Accepted December 212015 \\
Available online \\
December 242015 \\
\hline Keywords: \\
Human Capital \\
Human Resource \\
Accounting \\
Literature Review
\end{tabular}

A B S T R A C T

This study interrogates the meaning and conceptual nuances of human capital accounting and additionally highlights its empirical dimensions. A critical aspect of the concerns of the study borders on the validity of an interdisciplinary interpretation of the trajectories of human capital accounting. The methodology of the study is purposively the literature review. The study has attempted to underscore the essential aspects of the critical developments in the subject matter of human capital accounting. It has also tried to draw attention to the shortcomings of earlier studies, while showing the strengths of the influential types of such previous researches. Finally, the interdisciplinary thesis of the problem of the study was upheld, as having a large measure of validity. The empirical import of the concept of human capital accounting however, remains contentions. Consequently, continuous interdisciplinary research-engagement is recommended as an outcome of the study.

\section{Introduction}

What is human capital accounting? In the context of research and scholarship, does human capital accounting possibly belong to the social sciences or wholly to the field of accountancy and allied professions? In empirical terms, what does human capital accounting truly represent or embed? Is human capital accounting a tool of public administration or business administration? Is it an interdisciplinary area of theoretical and empirical engagement? Is human capital accounting researchable in public administration, specifically in the area of human resource management? Indeed, these are the research questions that motivated this study. Consequently, the methodology of the study is a literature review. In the process of examining the extant literature, answers to the aforementioned questions shall begin to unfold. This study is therefore considered significant because, there are still universally, grey areas to be sorted out on the subject matter of human capital accounting. It is intended that the results of the study will enkindle interest in further research on the subject matter of human capital accounting. Moreover, the primary purpose of a literature review is to display and underscore the state of affairs on a certain topic. Incidental to the presentation of such state of affairs, subsequent

* Corresponding author. Tel: +2348035523818

E-mail address: remiokeke@gmail.com (R. C. Okeke) 
researches are designed and solutions engendered to societal problems. An underlying assumption of this study therefore is that academic research should generate improvement in management systems (Flamholtz et al., 2002). Furthermore, in extant literature, the concepts of human capital, intellectual capital, human asset and human resource accounting are indeed, used interchangeably. In this review, while the conceptual underpinning remains human capital accounting, this exchangeability methodology shall also be maintained.

\section{Reviewing the conceptual prefixes: Human capital and its synonyms}

The core of this research is on human capital accounting. However, a critical aspect of the methodology of the study is the determination of what human capital as a distinct concept represents. Hence, according to Schultz (1961), among the few who had looked on human beings as capital, there were three distinguished names, the philosopher economist, Adam Smith, and von Thünen (Von Thünen \& Schumacher-Zarchlin, 1875) and Irving Fisher (Fisher, 1906). Nevertheless, according to Becker (1964), human capital refers to the productive capabilities of people. It is indicative of a trend in scholarship and organizational productivity whereby the generic issue of capital becomes fully perceived (and treated) as a value of economic means, capitalized in physical and human resources (Dobija, 1998). Consequently, human capital is about the quality of people within organizations. It is a metaphor about the economic potential of education and training (Teixeira, 2005). Human capital is also the profit lever of the knowledge economy (Bontis \& Fitz-Enz, 2002). It has also been defined (on an individual level) as the combination of these four factors: genetic inheritance; education; experience; and attitudes about life and business (Hudson, 1993 in Bontis \& Fitz-Enz, 2002). This leads us to what Becker (1962) denoted as the imbedding of resources in people or (more conventionally conceptualized) the investing in human capital. This is probably what Jones (2011), citing Hendrick (2002), calls the instantiation of ideas (e.g. surgical, engineering, managerial techniques) into people. Consequently, after developing a theory of investment in human capital or the instantiation of ideas into people, with an emphasis on empirical implications rather than on formal generalizations (Becker, 1962) what becomes the next critical trajectory in human capital theorization? Is it human capital accounting? However, let us in our interchangeability procedure; further bring to light, some conceptual synonyms to the concept of human capital

Human Resources (HR) are people's energies, skills, talents and knowledge, which are, or which potentially can be applied to the production of goods or rendering useful services (Micah et al., 2012). Human resources have been identified as one of the main sources of competitive advantage by many organizations in today's economy (Bassey et al., 2012). Human resources can be a source of sustained competitive advantage among organizations because, they meet the criteria of being valuable, rare, inimitable, and nonsubstitutable (Wright et al., 1993). Resource-based theorists therefore argue that human assets can be a source of sustainable advantage because, tacit knowledge and social complexity are hard to imitate (Coff, 1997). Then, is human capital, conceptually and empirically distinct from human resources? Wright et al. (1994) refer to human resources as the pool of human capital under the firm's control in a direct employment relationship. We also consider intellectual capital, which is packaged useful knowledge (Stewart, 1997). Brooking (1996) further describes intellectual capital as the term given to the combined intangible assets which enable the company to function. Furthermore, International Federation of Accountants (1998) in Brennan and Connell (2000) posits that intellectual capital can be thought of as the knowledge-based equity of a company. Citing Edvinsson and Malone (1997), Brennan and Connell (2000) highlight that in 1993, Leif Edvinsson, in a supplement to Skandia's annual report, used for the first time, the word "intellectual capital" instead of the accounting term, "intangible assets". Finally, in this section of the study, according to Bontis and Fitz-Enz (2002), human capital is also a primary component of the intellectual capital construct. 


\section{The focal literature review: Historical issues}

In historical context, we find in Singh and Singh (2009) that the first attempt to value human beings in monetary terms was made by Sir William Petty (1623-1687). However, the origin of human resource accounting, they highlight, is found in the work of Rensis Likert who was the first person to use the term "human asset" in the late 1950s. Nevertheless, for the first time, human resource accounting was implemented by Barry Corporation, Ohio (USA) in 1967, under the guidance of Likert and Pyle (Singh $\&$ Singh, 2009). Singh and Singh (2009) further posit that some notable efforts for the development of human resource accounting were subsequently made by Schultz (1960), William C Pyle (1967), Flamholtz (1971, 1972 and 1975), Morse (1973), Lev and Schwartz (1971), Jaggi and Lau (1974), Kenneth Sinclare (1978), etc. Accordingly, Roslender et al. (2006), citing Flamholtz (1974, 1985, 1999), opined that in due course, Flamholtz became the principal figure within human resource accounting, by contributing the concept's most authoritative textbooks. Furthermore, in this study, the historically hued submissions of Bullen and Eyler (2010) are found immensely appealing. They consequently demonstrate as follows:

"Research during the early stages of development of HRA was conducted at the University of Michigan, by a research team including the late organizational psychologist Rensis Likert, founder of the University of Michigan Institute of Social Research and well known for his work on management styles and management theory (Likert, 1961, 1967). Faculty member, R. Lee Brummet, and then Ph.D. candidates, William C. Pyle and Eric Flamholtz were in this team. The group worked on a series of research projects designed to develop concepts and methods of accounting for human resources. One outcome of this research (Brummet, Flamholtz \& Pyle, 1968) was a paper representing one of the earliest studies dealing with human resource measurement- and the one in which the term "Human Resource Accounting", was used for the first time."

In further consideration of the historical configurations, the Committee on Human Resource Accounting of the American Accounting Association (1973) has also disclosed that the economists were the first group to show interest in the area of human resource measurement. Subsequently, during the early and mid-1960's, shortly after the economists became interested in human capital, some accountants became concerned at the potential impact of ignoring a resource as significant as human capital, when making financial decisions. This concern therefore led to the development of a new field of inquiry in accounting called, human resource accounting. The earlier study of Lev and Schwartz (1971), from the disciplines of accounting/finance and economics, respectively, profoundly agree with this submission. Consequently, the purpose of human resource accounting is to improve the quality of financial decisions, made both internally and externally, concerning an organization (AAA, 1973). According to Tofangsaz et al. (2013) also, an American sociologist named Rensis Likert, at the beginning of the 1960s proposed the idea of human resource accounting, like many other theories of accounting for which the main designers were individuals who were not accountants. Then, the studies regarding human resource accounting were expanded, based on the theories of human relations management (Tofangsaz et al., 2013). We therefore begin to perceive some interdisciplinary possibilities and nuances in the theorizing of human capital accounting, stemming from its origins and current trajectories.

Citing Brummet et al. (1968), Flamholtz (1974) and Scarpello and Theeke (1989), Guthrie and Murthy (2009), further underline that the concept of human capital accounting became popular in the 1960s and 1970s, fueled by several articles that presented it as a means of measuring and reporting the value of human resources in monetary units. Many researchers and practitioners believed that human capital accounting would affect organizations, both internally and externally. However, there was a sudden decline in published subject matter in the late 1980s that led researchers to discuss the possible reasons 
for failure of the human resource cost and accounting concept, at both practical and scholarly levels. One possible reason proposed was that the main focus of human capital accounting (measuring the value of human capital) was never accomplished. According to Scarpello and Theeke (1989), [in Guthrie \& Murthy (2009)] therefore, the non-accomplishment (of measuring the value of human capital) was attributable to four major issues as follows:

(i) It was difficult to substitute unmeasurable surrogates for human resource value;

(ii) There was a lack of acceptable reliability standards for measurement instruments;

(iii) Even if measurement of the empirical referent was possible, there was a lack of validity;

(iv) The arguments in support of the need for HCA were unacceptable and could sometimes be negated (Guthrie \& Murthy, 2009).

As the conceptual interchangeability continues, in Abeysekera and Guthrie (2004), it appears as if the preferred terminology is human capital reporting. They also tended to use human capital management and accounting, as contrasted with only human capital accounting. But essentially, human capital accounting as a concept, appears to be more popular and better accepted by the non-accountancy researchers and human resource accounting, seems to be preferred by the core accountants. Nevertheless, the two concepts in particular and other allied derivatives can truly be used interchangeably. There are consequently, other analogous concepts such as human asset accounting (Robinson, 1974; McCowen, 1968), intellectual capital accounting (Roslender \& Fincham, 2001; Guthrie et al., 2012), competence accounting (Stenlund \& Hörte, 1999), etc. But human resource accounting (human capital accounting) is believed to be an old concept in corporate and academic research, while new in such social science areas as economics (Bokhari et al., 2012). According to Bassey et al. (2012), just as the field of human resource accounting has grown globally, significant interest in HRA has expanded and crossed over into fields other than accounting, including economics, organizational management and organizational culture and consequently inspired related studies. Skandia AFS, a Swedish financial services company, was one of the first companies to report the "hidden" intellectual capital assets of the business, as Skandia went on to develop one of the most important models, the Skandia Navigator, for managing intellectual capital (Brennan \& Connell, 2000).

\title{
4. Conceptual issue
}

Citing Kirfi and Abdullahi (2012), Flamholtz (1974) and Okafor and Jeroh (2010), Jeroh (2013) opines as follows:

\begin{abstract}
"Human capital accounting is the process of identifying and reporting the investments made in the human resources of an organization that are presently not accounted for in the conventional accounting practice. It involves measuring the costs incurred by the business firm and other organizations to recruit, select, hire, train and develop human capital. Human capital accounting can be described as the process of identifying, measuring and communicating information about human resources in order to facilitate effective management within an organization. It is an extension of the accounting principles of matching costs and revenues and of organizing data to communicate relevant information in financial terms."
\end{abstract}

The Committee on Human Resource Accounting, of the American Accounting Association (1973) defines human resource accounting as the process of identifying and measuring data about human resources and communicating this information to interested parties. Mayo (2001) believes that human resource accounting, or human asset accounting, has been primarily developed in the United States under the guidance of Professor Eric Flamholz. He further posits that the truth about human resource accounting is that it is not a well-known discipline, and it has not been generally adopted by either the financial or HR communities. According to Stanko et al. (2014), human asset accounting (human 
capital accounting) aims to quantify, in dollar value, how valuable an employee is to the company that they are employed by. Does this dollarization not appear debasing? They further posit:

"Human capital accounting is a highly complex process. In fact, it is so difficult that there has been no truly effective means ever developed. The complexity lies in the reality that there are hundreds of factors that comprise an employee's value. Additionally, employees are human beings with free will. Because they have free will, the employees can be influenced but never completely controlled like other assets can be. They cannot be owned like a building, patent, or security can be."

Morse (1973) cited in Bontis (2003) might have added a curious dimension to these conceptualizations. According to Morse, human resource accounting has two components: human asset accounting and human capital accounting. Consequently, while human asset accounting is concerned with determining the value of the human resources employed in an organization to the organization, human capital accounting is concerned with the determining of the value of the human resources employed in an organization, to the employees of that organization. According to Morse in Bontis (2003) therefore, most accountants are interested in human asset accounting, with its emphasis on organizational reporting but intellectual capital research had extended this line of thinking to embody both an external and internal focus. Consequently, much of the initial intellectual capital reporting that most firms engaged in was for internal purposes, with the ultimate goal of publishing an external document for stakeholders (Bontis, 2003). In this study, no other sources corroborated this viewpoint. Another curious contribution posits that Human Resource Accounting (HRA) involves accounting for the company's management and employees as human capital that provides future benefits (Bullen \& Eyler, 2010; Kashive, 2013). Indeed, an immense disorder, is embedded in this particular conceptualization.

It does appear however as if these conceptual diffusions and conceptual disorders have been dispensed with, in contemporary human capital (human resource) theorizations. Therefore, still according to Bullen and Eyler (2010), human resource accounting (HRA) involves accounting for expenditures related to human resources as assets, as opposed to traditional accounting which treats these costs as expenses that reduce profit. To Enyi and Akindehinde (2014), human resource accounting is in simple terms, accounting for the value of people in organization to enhance information for decision making by the users of financial information. Their definition is squarely tied to financial information and their usages. Does that now settle the disputations? But human resource accounting (human capital accounting) has continued to experience something of a revival (Toulson \& Dewe, 2004).

\section{The empirical issues}

According to Kirfi and Abdullahi (2012), it is essential to note that human resource accounting is comparatively a new but a very sensitive development in the accounting field. And there appears to be a somewhat consensus that its adoption, is a response to the challenging questions posed by the prevailing trends, which view human resource as most instrumental in the production process. Hence, according to Flamholtz and Main (1999), despite the obvious shift in economic reality, the management accounting field had not yet developed sufficient tools to measure the value of intellectual capital. They saw human resource accounting as one accounting tool that is directly relevant to such measurement. Miller (1996) thus adds that spurred by the emerging "knowledge economy", government policy makers, human resource managers, financial accountants and educators, are developing methods for systematically evaluating and recording knowledge assets acquired through experience, education and training. Miller's firm position is that it is possible in terms of economic theory, and feasible from the perspective of accounting practices, to implement new human capital information and decision-making systems. This entails human resource accounting. Therefore, human resource accounting is considered as applying accounting concepts and methods in human resource management and it can be considered 
as assessing, monitoring, costing and valuating tools for human resources of every organization (Bavali \& Jokar, 2014).

Jeroh (2013) was actually an examination of the relationship between human capital accounting and the comparability of financial statements in Nigeria. He found a significant relationship between the variables. Therefore, human capital accounting is a necessary component of a credible financial statement. But Bokhari et al. (2012) suggested that the concept of human capital accounting is struggling for acceptance in the financial statements. Indeed, according to Becker (2009), education and training are the most important investments in human capital. However, how would the impact of education and training be measured and the measurement-outcome recognized and retained on sustainable basis? Furthermore, Dean et al. (2012) investigated whether or not human capital should be accounted for, on the balance sheet. The results of their study revealed that $87 \%$ of the respondents held the belief that human capital should not be accounted for, and reported on the balance sheets, principally because, there is no consistent way to measure human capital. There are some opinions, they highlighted, that human capital should be valued, but perhaps the financial statements are not the proper place for such numbers. It might be a good idea they concluded, to have a separate human capital report that would provide statistics and other facts about a company's stock of human capital. Hence, citing Bullen (2007) Bullen and Eyler (2010) had opined that even if human assets are not reported on the face of external financial statements, HRA can play a crucial role in internal managerial decisionmaking, and HRA measures can be used to show that investments in a company's human resources may result in long-term profit for the company.

Findings of Jelil et al. (2014) however suggest that the majority opinion among scholars in the field of accounting is that human capital should be included in the statement of financial position. Then, in Ikpefan et al. (2015) 98.4\% of the sample of the study agreed that human resources expenditure should be capitalized and treated as assets rather than written off to profit and loss accounts. But the critical question remains whether human resources satisfy the test to be classified as assets (Ravichandra et al., 2015). Additionally, after examining the utilitarian dimensions of the existing models of human resource accounting, Bavali and Jokar (2014) concludes:

'By disregarding employees' value in managerial reports and giving quantitative values to them, we cannot expect to make any progress for development in the organizational environment. Progressing and evaluating human resource accounting have not reached to an adoptable level. Using current human resource models is complex, and managers and human resource accountants in various organizations cannot analyze them. Therefore, these models do not have much chance to remain in this practical field and we hope to meet expected progress by providing new models of measuring human resource accounting and to see all firms and organizations measure their own human resource and develop to higher levels."

Guthrie and Murthy (2009) argued that the existing research was concentrated on developed countries and the policies and frameworks were derived from these countries and could be suitable only to such developed countries. The developing and emerging economies, they argued, might not be able to adopt these frameworks, since their human capital agenda could be different. They gave the example of India, as an emerging economy, rich in human competence (second highest populated country) which had been the outsourcing destination for many countries of the world. The country, they further contended, did not have the problem of an ageing population that was faced by many developed countries, which means the existing HCA framework might not be suitable for India. Guthrie and Murthy (2009) thus opined that new frameworks could be developed and tested in developing and emerging economies. This could be compared with the existing frameworks and policies that would assist in understanding and refining the frameworks that had so far been developed, in order to have one common framework that could suit all the countries. Are all the observations of Guthrie and Murthy (2009), currently 
germane? Furthermore, when Islam et al. (2013) posit that human resource accounting (HRA) is a new branch of accounting, is it a branch of accounting with universal applicability and global import or a new branch with local peculiarities? In other words, to what extent is human resource accounting a new branch of accounting?

According to Steen and Welch (2011), the aim of human resource accounting is to contribute to the management of the organization, by optimizing the value of its human assets. Citing Mayo (2005) and Verma and Dewe (2008), highlighted that human resource accounting literature centers on developing measures that can adequately capture and report, in a tangible form, the worth of people and their contribution to the organization. Therefore, according to Guthrie and Murthy (2009), human capital accounting has become a legitimate area for accounting research and it is multi-disciplinary and multifocused in nature. Luthy (1998) thus opined that intellectual capital (human capital) is not collateral in the traditional sense, but its value in creating future cash flows may be more valuable than any other asset shown on the balance sheet. Hence, Bontis (2001) concludes that if shareholders and analysts agree that intellectual capital disclosure is beneficial in explaining business performance, then companies will have no choice but to appease their audience. Besides, Ijeoma et al. (2013) opined that if truly, our greatest assets are our people, then there is urgent need for their values to be evaluated, recorded in books, operated (sic) and disclosed in the financial statements. Furthermore, in canvassing for proper disclosure of human capital in financial statements, Hai-Ming and Ku-Jun (2003) opined that the usefulness of financial statements was diminishing. Has human capital accounting stemmed the tide of this diminishing returns?

\section{Concluding remarks}

Human capital accounting is essentially, the identification and recognition in specific terms, of the human value in organizational productivity. In the context of research and scholarship, it possesses multidisciplinary trajectories. In empirical terms, its import is contentious. Indeed, a literature review may not be an exhaustive documentation. However, it must highlight the essential aspects of the critical developments in the subject matter or topical issue. It must be authoritative enough to uncover the shortcomings of earlier studies and furthermore, show the strengths of the influential types of such previous researches. Invariably, a good literature review would chart a course for future investigations. In precise terms, a literature review of some significance is expected to expose the gaps in extant literature. It is principally from such gaps that further researches are framed. Consequently, this study has attempted to conform to the foregoing requirements of an impactful investigation. The study is concluded by stating that the empirical import of human capital (human resource accounting) will be difficult to convincingly establish and universally recognized. This study has further highlighted these difficulties and recommends that further investigations be continued from here, in strongly determining beyond alluring theorizations, the empirical importance of human capital accounting.

\section{References}

Abeysekera, I., \& Guthrie, J. (2004). Human capital reporting in a developing nation. The British Accounting Review, 36(3), 251-268.

American Accounting Association (1973). Report of the Committee on Human Resource Accounting. The Accounting Review, Supplement to 48 (-), 169-185.

Bassey, B. E., \& Tapang, A. T. (2012). Capitalized human resources cost and its influence on corporate productivity: A study of selected companies in Nigeria. International Journal of Financial Research, 3(2), 48-59

Becker, G. S. (1962). Investment in human capital: A theoretical analysis. The Journal of Political Economy, 70(49), 9-49.

Becker, G. S. (1964). Human capital. New York: Columbia University Press for the National Bureau of Economic Research. 
Becker, G. S. (2009). Human capital: A theoretical and empirical analysis, with special reference to education. Chicago: University of Chicago Press.

Bavali, E., \& Jokar, I. (2014). A new approach for measuring human resource accounting. Management Science Letters, 4(2), 335-340.

Bokhari, I. H., Qureshi, T. M., Bashir, F., \& Hijzi, S. T. (2012). The yes, no decision is easy now: Is human capital accounting challenge for accountants. African Journal of Business Management, 6(15), 5281-5287.

Bontis, N. (2001). Assessing knowledge assets: a review of the models used to measure intellectual capital. International Journal of Management Reviews, 3(1), 41-60.

Bontis, N. (2003). Intellectual capital disclosure in Canadian corporations. Journal of Human Resource Costing \& Accounting, 7(1), 9-20.

Bontis, N., \& Fitz-Enz, J. (2002). Intellectual capital ROI: a causal map of human capital antecedents and consequents. Journal of Intellectual capital, 3(3), 223-247.

Brennan, N \& Connell, B. (2000). Intellectual capital: current issues and policy implications. Journal of Intellectual capital, 1(3), 206-240.

Brooking, A. (1996). Intellectual Capital: Core Asset for the Third Millennium Enterprise. New

York: International Thomson Business Press,

Brummet, L.R., Flamholtz, E. and Pyle, W.C. (1968). Human resource measurement-a challenge for accountants, Accounting Review, 43(2), 217-24.

Bullen, M. L. (2007). Human resource accounting: A useful tool for measurement and management in organizations. Leadership and Organizational Management Journal, 5(-), 85-103.

Bullen, M. L., \& Eyler, K. A. (2010). Human resource accounting and international developments: implications for measurement of human capital. Journal of International Business and Cultural Studies, 3(3), 1-16.

Coff, R. W. (1997). Human assets and management dilemmas: Coping with hazards on the road to resource-based theory. Academy of Management Review, 22(2), 374-402.

Dean, Passard C., McKenna, K., \& Krishnan, V. (2012). Accounting for Human Capital: Is the

Balance Sheet Missing Something? International Journal of Business and Social Science, 3(12), 6164.

Dobija, M. (1998). How to place human resources into the balance sheet? Journal of Human Resource Costing \& Accounting, 3(1), 83-92.

Edvinsson, L., \& Malone, M. (1997). Intellectual Capital: The Proven Way to Establish Your Company's Real Value by Measuring Its Hidden Brain Power. London: Piatkus.

Enyi, E. P., \& Akindehinde, A. O. (2014). Human resource accounting and decision making in postindustrial economy. International Journal, 2(1), 19-35.

Fisher, I. (1906). The nature of capital and income. New York: The Macmillan Company.

Flamholtz, E. G. (1974). Human Resource Accounting. California: Dickenson Publishing Company.

Flamholtz, E. (1974). Human resource accounting: a review of theory and research. Journal of Management Studies, 11(1), 44-61.

Flamholtz, E. G. (1985). Human Resource Accounting, San Francisco: Jossey-Bass.

Flamholtz, E. G. (1999) Human Resource Accounting, Boston: Kluwer Academic Publishers.

Flamholtz, E. G., Bullen, M. L., \& Hua, W. (2002). Human resource accounting: a historical perspective and future implications. Management Decision, 40(10), 947-954.

Flamholtz, E. G., \& Main, E. D. (1999). Current issues, recent advancements, and future directions in human resource accounting. Journal of Human Resource Costing \& Accounting, 4(1), 11-20.

Guthrie, J., \& Murthy, V. (2009). Past, present and possible future developments in human capital accounting: a tribute to Jan-Erik Gröjer. Journal of Human Resource Costing \& Accounting, 13(2), 125-142.

Guthrie, J., Ricceri, F., \& Dumay, J. (2012). Reflections and projections: a decade of intellectual capital accounting research. The British Accounting Review, 44(2), 68-82.

Hai-Ming, C., \& Ku-Jun, L. (2003). The measurement of human capital and its effects on the analysis of financial statements. International Journal of Management, 20(4), 470-478 
Hendricks, L. (2002). How Important Is Human Capital for Development? Evidence from Immigrant Earnings. American Economic Review, 92(1), 198-219.

Hudson, W. (1993), Intellectual Capital: How to Build it, Enhance it, Use it. New York, NY: John Wiley.

Ijeoma, N., Bilesanmi, A. O., \& Aronu, C. O. (2013). Determining the contribution of human resource accounting (HRA) on financial statement of Nigerian banks using the mantel test analysis. International Journal of Scientific \& Technology Research, 2(10), 51-55.

Ikpefan, O. A., Kazeem, B. L. O., \& Taiwo, J. (2015). Human capital accounting and performance of microfinance banks (MFB) in Nigeria. Research Journal of Finance and Accounting, 6(1), 65-75.

International Federation of Accountants (1998). The Measurement and Management of Intellectual Capital. New York, NY: International Federation of Accountants (IFAC).

Islam, M. A., Kamruzzaman, M., \& Redwanuzzaman, M. (2013). Human resource accounting: Recognition and disclosure of accounting methods \& techniques. Global Journal of Management and Business Research, 13(3), 1-9.

Jelil, A. A., Olotu, A. E., \& Omojola, S. O. (2014). Optimizing the effectiveness of financial reporting through human resources accounting. International Journal of Accounting Research, 2(1), 30-42.

Jeroh, E. (2013). Human capital accounting and the comparability of financial statements in Nigeria. Journal of Accounting Management, 3(2), 53-63.

Jeroh, E., \& Okafor, C. A. (2010). Human capital figures and the balance sheet: Implication for personnel selection decisions in Nigeria. Indian Journal of Multidisciplinary Research, 6(2), 329340.

Jones, B. F. (2011). The human capital stock: a generalized approach (No. w17487). National Bureau of Economic Research.

Kashive, N. (2013). Importance of human resource accounting practices and implications of measuring value of human capital: Case study of successful PSUs in India. XIMB Journal of Case Research, 4(02), 113-143.

Kirfi, M. M., \& Abdullahi, A. (2012). Human capital accounting: Assessing possibilities for domestication of practice in Nigeria. Research Journal of Finance and Accounting, 3(10), 57-63.

Lev, B \& Schwartz, A. (1971). On the use of the economic concept of human capital in financial statements. The Accounting Review, 46(1), 103-112.

Likert, R.M. (1961). New Patterns of Management. New York: McGraw Hill Book Company.

Likert, R. M. (1967). The Human Organization: Its Management and Value. New York: McGraw-Hill Book Company.

Luthy, D. H. (1998). Intellectual capital and its measurement. In Proceedings of the Asian Pacific Interdisciplinary Research in Accounting Conference (APIRA), Osaka, Japan.

Mayo, A. (2001). Human Value of the Enterprise. London: Nicholas Brealey Publishing.

Mayo, A. (2005). Helping HR to understand the strategic value chain. Strategic HR Review, 5(1), 3235.

McCowen, P. (1968). Human asset accounting. Management Decision, 2(2), 86-89.

Micah, L. C., Ofurum, C. O., \& Ihendinihu, J. U. (2012). Firms financial performance and human resource accounting disclosure in Nigeria. International Journal of Business and Management, 7(14), 67-75.

Miller, R. (1996). Measuring What People Know. Human Capital Accounting for the Knowledge Economy. Washington, DC: OECD Publications and Information Center,

Morse, W. J. (1973). A note on the relationship between human assets and human capital. The Accounting Review, 48(3), 589-593.

Ravichandra, T., Chacko, A., \& Ganguly, S. (2015). Human capital accounting. International Journal of Research in Finance and Marketing, 5(1), 18-25.

Robinson, D. F. (1974). Human asset accounting. Long Range Planning, 7(1), 58-60.

Roslender, R., \& Fincham, R. (2001). Thinking critically about intellectual capital accounting. Accounting, Auditing \& Accountability Journal, 14(4), 383-399. 
Roslender, R., Stevenson, J., \& Kahn, H. (2006). Employee wellness as intellectual capital: an accounting perspective. Journal of Human Resource Costing \& Accounting, 10(1), 48-64.

Scarpello, V., \& Theeke, H.A. (1989). Human resource accounting: A measured critique. Journal of Accounting Literature, 8 (-), 265-80.

Schultz, T. W. (1961). Investment in human capital. The American Economic Review, 51(1), 1-17.

Singh, H. K., \& Singh, V. (2009). Human resource accounting practices in infosys technologies ltd: An evaluation. Management Insight, 5(1), 67-73.

Stanko, B. B., Zeller, T. L., \& Melena, M. F. (2014). Human asset accounting and measurement: Moving Forward. Journal of Business \& Economics Research (JBER), 12(2), 93-104.

Steen, A., \& Welch, D. (2011). Are accounting metrics applicable to human resources? The case of return on valuing assignments. Australasian Accounting, Business and Finance Journal, 5(3), 5772.

Stenlund, K. L., \& Hörte, S. A. (1999, June). Competence accounting-methods for measuring and valuing key competencies. In European Operations Management Association VI International Annual Conference "Managing Operations Networks", Venice, Italy (pp. 7-8).

Stewart, T. A. (1997). Intellectual Capital. New York: Doubleday,

Teixeira, P. N. (2005). The Human Capital Revolution in Economics. History of Economic Ideas, 13(2), $129-148$.

Tofangsaz, A., Vakilifard, H., Talebnia, G., \& Pour, M. G. (2013). An Investigation into Methods of Human Resource Valuation in the Iranian Private Banks (The Case Study of Shahr Bank). Journal of Basic and Applied Scientific Research, 3(8), 727-739.

Toulson, P. K., \& Dewe, P. (2004). HR accounting as a measurement tool. Human Resource Management Journal, 14(2), 75-90.

Von Thünen, J. H., \& Schumacher-Zarchlin, H. (1875). Der isolirte staat in beziehung auf landwirtschaft und nationalökonomie (Vol. 1). Wiegant, Hempel \& Parey.

Verma, S \& Dewe, P. (2008). Valuing human resources: Perceptions and practices in UK organizations. Journal of Human Resource Costing and Accounting, 12(2), 102-123.

Wright, P. M., McMahan, G. C., \& McWilliams, A. (1994). Human resources and sustained competitive advantage: a resource-based perspective. International Journal of Human Resource Management, 5(2), 301-326. 